\title{
THE EFFECTS OF SALINITY ON THE DEVELOPING EGGS AND LARVAE OF THE HERRING
}

\author{
By F. G. T. Holliday and J. H. S. Blaxter \\ Marine Laboratory, Aberdeen
}

(Text-figs. I-8)

The herring (Clupea harengus L.) deposits its eggs in the coastal waters around the North Atlantic Ocean, North Sea, and Baltic Sea. The salinity on the spawning grounds may vary from about $35 \%$ to $5 \%$. For instance, Brandhorst (1959) reports that successful spawning took place in the Kiel Canal in salinities down to $5 \%$, and Ford (1929) records that ripe herring have been found in the Tamar estuary. In a series of experiments Ford found that the eggs of herring could be successfully fertilized and incubated even in a salinity of $4.8 \%$. McMynn \& Hoar (1953) investigated the effect of salinity on the development of the Pacific herring $C$. pallasii and found it had a wide tolerance, the lower level being somewhere between 0 and $6 \%$.

The experiments now described were carried out as part of an investigation into osmoregulation in the herring, and particularly to find the range of conditions which herring eggs and larvae might tolerate both in nature and in rearing tanks. An extension of this work into the temperature tolerance of herring larvae is described by Blaxter (1960).

\section{MATERIALS AND METHODS}

Ripe gonads were obtained from herring caught in the Firth of Clyde in February and off the Scottish East Coast in September and the eggs fertilized in the laboratory. The techniques of storage and fertilization are described by Blaxter (1955). After fertilization, eggs were incubated in sea water of salinity $3 \mathrm{I}-32 \%$ at temperatures of $\mathrm{II} \cdot 2-\mathrm{II} \cdot 7^{\circ} \mathrm{C}$ in 501 . glass tanks. Smaller numbers of larvae were incubated in water of other salinities in $500 \mathrm{ml}$. jars; the water in these jars was changed every second day. Low salinity water was made up by adding distilled water to sea water and high salinity water by adding sodium chloride to sea water.

Most of the experiments were carried out on the spring-spawned larvae while a few confirmatory ones were done in the autumn. 


\section{FERTILIZATION}

Prior to fertilization both eggs and sperm normally undergo changes of environment, i.e. from the body fluids of the parent to sea water. In addition the sperm then penetrate the eggs. Thus the gametes must be resistant to osmotic stress, especially the sperm; its large surface/volume ratio and small diffusion pathways would seem to make it particularly susceptible.

To find out the tolerance of the gametes to salinity, fertilizations were carried out in salinities of $5 \cdot 9, \mathrm{II} \cdot 5,22 \cdot 7,33 \cdot 6,4 \mathrm{I} \cdot 6,45 \cdot 0$ and $52 \cdot 5 \%$; the results are shown in Fig. I. Fertilization was complete in salinities $22 \cdot 7-$ $52 \cdot 5 \%$. It fell off in salinities $11 \cdot 5$ and $5.9 \%$.

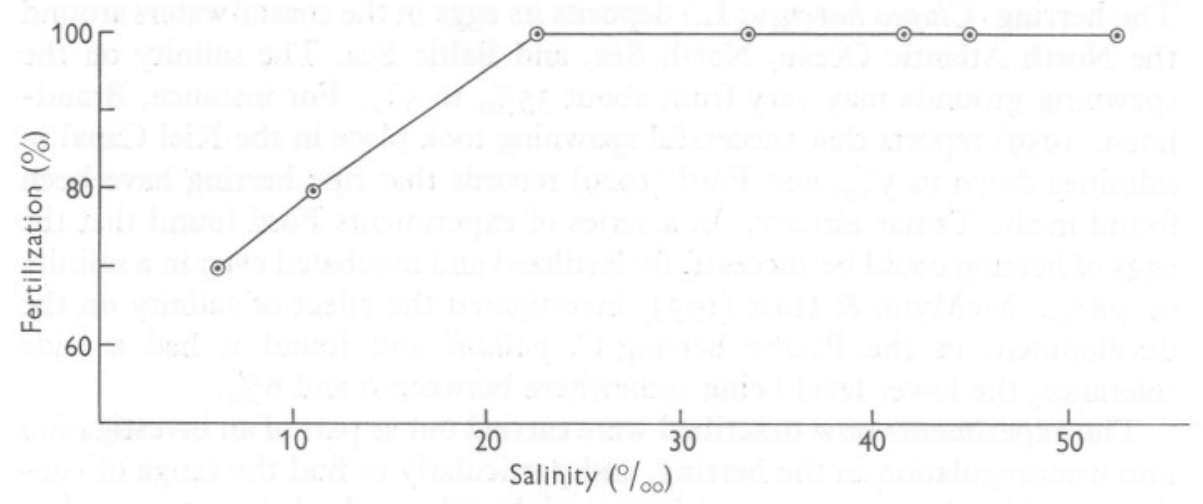

Fig. I. Percentage fertilization of eggs.

\section{EMBRYONIC DEVELOPMENT AND HATCHING}

Krogh (1939), in a review on the subject, concludes that the developing teleost egg is not independent of the environmental salinity. In these experiments a number of observations were made to test this dependence in the herring egg.

Size of egg. The average diameter of eggs incubated in different salinities is shown in Fig. 2. It will be seen that the diameter increases in the lower salinities, due to an increase in water content.

Osmotic concentration of the eggs. Experiments were done to test whether the osmotic concentration (and therefore the proportion of water) varied in eggs incubated in different salinities. Freezing-point depressions $(\Delta)$ were determined for the perivitelline fluid and the embryonic fluid, using the apparatus described by Ramsay (1949) and Ramsay \& Brown (1955).

Samples of the egg contents were taken after placing the egg under medicinal paraffin in a watch-glass coated with a lacquer of bakelite damada. A fine capillary, made of silica glass, was inserted into the perivitelline fluid and a 
small sample sucked in. This sample was sealed between two layers of paraffin by sucking paraffin into the capillary before and after taking the sample.

It was much more difficult to sample the body fluid of the embryo. The embryo was removed from the egg (under paraffin) and cleared of perivitelline fluid. The capillary was inserted into the posterior trunk region. Due to the difficulty of avoiding contamination with yolk many samples had to be discarded.

The results are shown in Table $\mathrm{I}$.

TABLE 1. OSMOTIC CONCENTRATIONS OF EGGS

(7-8 days post-fertilization.)

\begin{tabular}{|c|c|c|c|c|c|}
\hline \multicolumn{2}{|c|}{ Salinity $\%(\Delta)$} & \multicolumn{2}{|c|}{ Perivitelline fluid } & \multicolumn{2}{|c|}{ Embryonic fluid } \\
\hline Fertilization & Incubation & $\Delta$ & $\% \mathrm{NaCl}$ & $\Delta$ & $\% \mathrm{NaCl}$ \\
\hline $10.9(0.65)$ & $10.9(0.65)$ & $\begin{array}{l}0.56 \\
0.57\end{array}$ & $\begin{array}{l}9 \cdot 3 \\
9 \cdot 5\end{array}$ & $\begin{array}{l}0.70 \\
0.68\end{array}$ & $\begin{array}{l}\text { II } \cdot 66 \\
\text { II } \cdot 33\end{array}$ \\
\hline $32 \cdot 3(I \cdot 94)$ & $10.9(0.65)$ & 0.64 & 10.7 & 0.68 & II. 33 \\
\hline $32 \cdot 3(\mathrm{I} \cdot 94)$ & $32 \cdot 3(\mathrm{I} \cdot 94)$ & $\begin{array}{l}0.67 \\
\Gamma \cdot 60\end{array}$ & $\begin{array}{l}11 \cdot 2 \\
26 \cdot 7\end{array}$ & $\stackrel{0.69}{-}$ & II.5O \\
\hline & & $\begin{array}{r}r \cdot 67 \\
\end{array}$ & $27 \cdot 8$ & - & - \\
\hline $32 \cdot 3(I \cdot 94)$ & $47 \cdot 8(2 \cdot 87)$ & $\begin{array}{l}2.07 \\
2.09\end{array}$ & $\begin{array}{l}34.5 \\
34.8\end{array}$ & 0.90 & 15.0 \\
\hline $47 \cdot 8(2 \cdot 87)$ & $47 \cdot 8(2 \cdot 87)$ & $\begin{array}{l}2 \cdot 73 \\
2 \cdot 69\end{array}$ & $\begin{array}{l}45 \cdot 5 \\
44 \cdot 8\end{array}$ & $\overline{-}$ & $\overline{-}$ \\
\hline
\end{tabular}

TABLE 2. OSMOTIC CONCENTRATION OF EGGS AFTER TRANSFER

\begin{tabular}{|c|c|c|c|c|c|c|}
\hline \multicolumn{2}{|c|}{ Salinity $\%(\Delta)$} & \multirow{2}{*}{$\begin{array}{l}\text { Time } \\
\text { after } \\
\text { transfer } \\
\text { (h) }\end{array}$} & \multicolumn{2}{|c|}{ Perivitelline fluid } & \multicolumn{2}{|c|}{ Embryonic fluid } \\
\hline Incubation & Transfer & & $\Delta$ & $\% \mathrm{NaCl}$ & $\Delta$ & $\% \mathrm{NaC}$ \\
\hline \multirow{4}{*}{$32 \cdot 3(I \cdot 94)$} & 10.9( & 24 & 0.64 & 10.7 & 0.63 & 10.5 \\
\hline & & $\begin{array}{l}24 \\
24\end{array}$ & $\begin{array}{l}r \cdot 67 \\
2 \cdot 46\end{array}$ & $\begin{array}{l}27 \cdot 8 \\
41 \cdot 0\end{array}$ & 二 & 二 \\
\hline & $\begin{array}{l}47.8(2.87) \\
10.9(0.65)\end{array}$ & $\begin{array}{l}44 \\
48\end{array}$ & $\begin{array}{l}2.46 \\
0.61\end{array}$ & IO. 2 & - & \\
\hline & $\begin{array}{l}32.3(\mathrm{I} \cdot 94) \\
47.8(2.87)\end{array}$ & 48 & $I \cdot 70$ & $28 \cdot 3$ & - & - \\
\hline
\end{tabular}

The water content of the perivitelline fluid is higher in eggs incubated at the low salinities. This content, however, also depends on the salinity at fertilization. Very limited readings for the embryos suggest that their water content is also higher at the lower salinities.

Eggs were also transferred from sea water to a higher and a lower salinity before hatching, and freezing-point determinations made after 24 and $48 \mathrm{~h}$. The results are shown in Table 2 . The concentration of the perivitelline fluid seems to be greatly dependent on that of the environment but there does seem to be a slight measure of regulation. Unfortunately the samples from the embryos had nearly all to be discarded.

Time to hatching and percentage hatching. The time from fertilization to that when $50 \%$ of the larvae hatched was the same (II days) for all salinities 


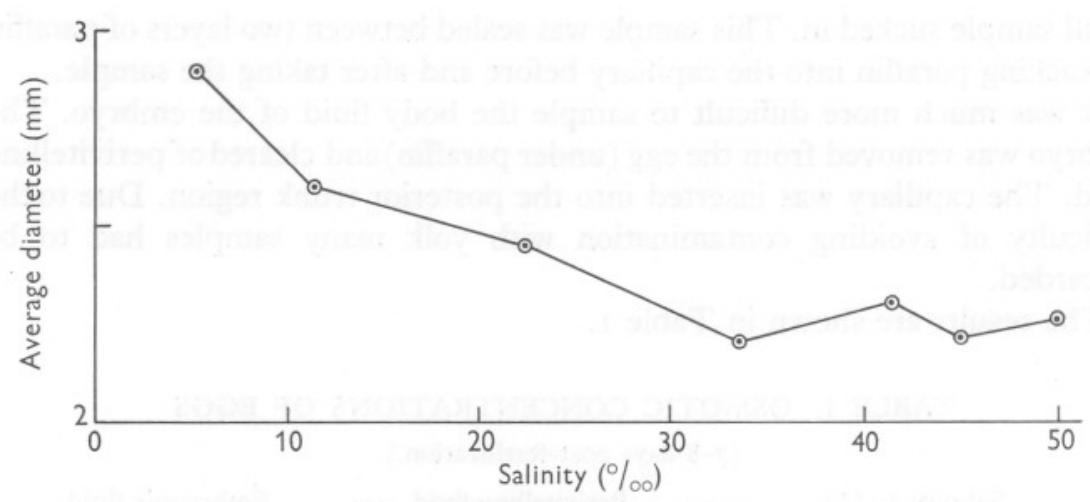

Fig. 2. Size of developing eggs.

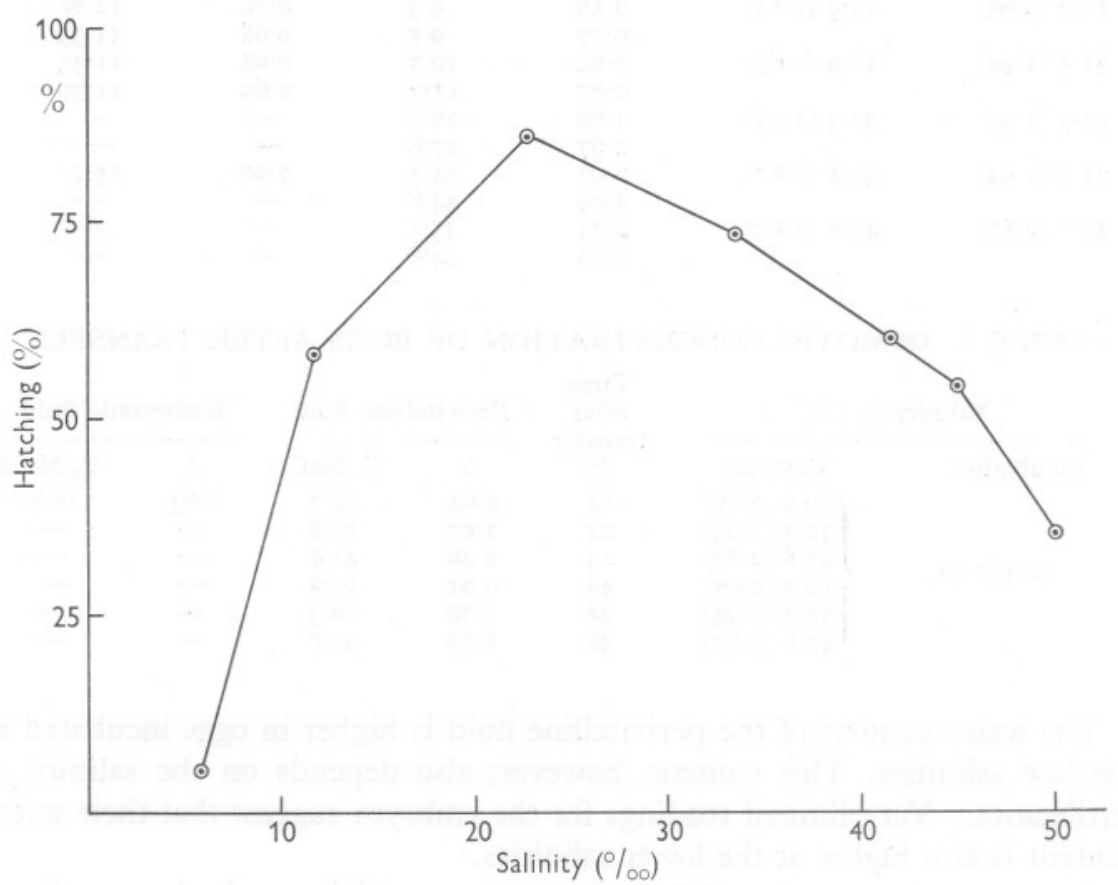

Fig. 3. Percentage hatching of eggs.

of incubation except 5.9 and $\mathrm{II} \cdot 5 \%$, where the time to hatching was about 2 days longer.

The percentage hatching in different salinities is shown in Fig. 3. There appears to be an optimum range of salinity from about 20 to $35 \%$ and it appears that extremes of salinity impose more limitations on development. 


\title{
LARVAE
}

Morphological characters. Observations were made on length, weight, appearance and activity of larvae on hatching. The results are shown in Table 3.

TABLE 3. LENGTH, WEIGHT AND APPEARANCE OF NEWLY HATCHED LARVAE

(Each value is the mean of ten larvae.)

Incubation
salinity $(\%)$
$5 \cdot 9$
II.
$22 \cdot 7$
$33 \cdot 6$
$41 \cdot 6$
$45 \cdot 0$
$52 \cdot 5$

$\begin{array}{cc}\begin{array}{c}\text { Mean length (mm) } \\ \text { (and S.E.) }\end{array} & \begin{array}{c}\text { Mean } \\ \text { weight (mg) }\end{array} \\ 8.75 \pm 0.037 & 0.90 \\ 7.85 \pm 0.085 & 0.90 \\ 7.90 \pm 0.10 & 0.84 \\ 6.43 \pm 0.075 & 0.75 \\ 6.70 \pm 0.16 & 0.70 \\ 6.90 \pm 0.11 & 0.71 \\ 6.75 \pm 0.053 & 0.60\end{array}$

\author{
Colour and shape \\ of yolk sac \\ Pale yellow; oval \\ Dark yellow; spherical \\ Intense yellow, shrunken
}

The larvae hatched in salinities of $5 \cdot 9, \mathrm{II}_{1} \cdot 5$ and $22 \cdot 7 \%$ were larger but the time to hatching tended to be longer in the lower salinities. There was, however, a negative correlation between weight and salinity. This was probably a reflexion of water content (see later description of freezing-point determinations) as larvae in high salinities would have a tendency to be dehydrated. This probably also explains the difference in appearance of the yolk sac and Ford's (1929) observations that a decrease in the specific gravity of larvae took place with reduced salinity of incubation.

Salinity tolerance. The range of salinities in which survival is possible is restricted to those in which the regulatory mechanisms of the animal can maintain the body fluids within certain limits. Outside this range, despite the functioning of the regulatory mechanisms, there is a continuous change of the body fluids from normal. The survival time will then depend, first, on the speed of the change, which will be greatest in the more extremes of salinity, and secondly, on the ability of the cells to function in conditions which are not optimum. Larvae were transferred in batches of ten from incubation salinities of II.5, 20.5, 33.6 and $52.5 \%$ to $500 \mathrm{ml}$. jars holding a wide range of salinities from o to $70 \%$. The criteria of tolerance used were that $50 \%$ of the larvae should survive 24,48 or $168 \mathrm{~h}$ immersion in the particular salinity. Thus the upper and lower limits of tolerance for $24 \mathrm{~h}$ may be considered as the high and low lethal salinities for herring larvae on the same basis used by Blaxter (1960) for temperature tolerance.

The results for these experiments are shown in Fig. 4. The most striking result is the extremely wide salinity tolerance, from $\mathrm{I} \cdot 4$ to $60 \%$, over $24 \mathrm{~h}$ to $2.5-52.5 \%$ over I68 h. A few larvae even survived in $60 \%$ for $\mathrm{I} 68 \mathrm{~h}$. At the end of the $24 \mathrm{~h}$ period some larvae were still alive (i.e. the heart was 


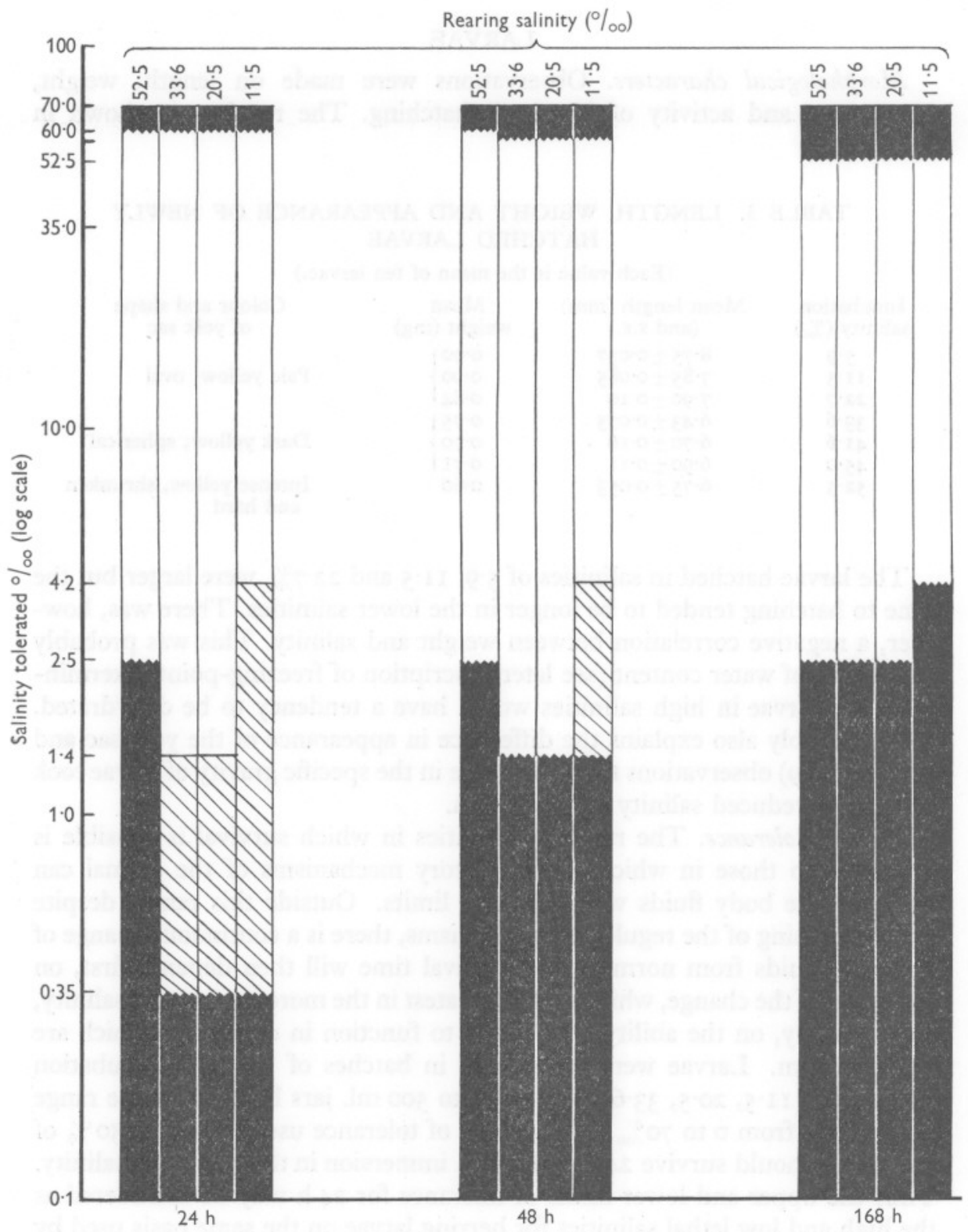

Fig. 4. Salinity tolerance of herring larvae. Shaded areas, $<50 \%$ survival. Unshaded areas, $>50 \%$ survival. Hatched areas, $>50 \%$ survival, inactive but heart beating. 
beating) but inactive, between salinities from 0.35 to $1.4 \%$. This is also shown in Fig. 4. There is a tendency for larvae incubated in the low salinities to have a greater tolerance of low salinities and larvae incubated in high salinities to have a greater tolerance of high salinities, but this is not consistent. There was very little tolerance of distilled water; the larvae either died or became inactive within $45 \mathrm{~min}$. In this period of inactivity, which sometimes lasted for as long as $\mathrm{I} 8 \mathrm{~h}$ before death, the rate of heart beat was reduced from a normal average rate of about I.I beats/second to an average of 0.7 beats/ second. The body, and in particular the eyes swelled considerably before death. However, larvae recovered if they were transferred back to sea water within $\mathrm{I} 8 \mathrm{~h}$ of being put in distilled water.

No difference was found between the salinity tolerance of spring- and autumn-spawned larvae.

Weight changes. It is well known (Summer, I905; Black, I948) that when fish are transferred from one salinity to another they undergo weight changes which correspond with movements of water into and out of the body.

Batches of fifty larvae were transferred from a salinity of $33.6 \%$ to salinities of 3.0 , II. $4,33.6$ (control), 45.0 and $56.3 \%$. The weight of the larvae at the start of the experiment was measured by taking two samples of twenty larvae straight from $33.6 \%$. All weighings involved killing the larvae, and were done in a consistent manner. The larvae were removed from the water and placed on filter-paper to absorb excess water. For each sample identical methods of handling and exposure to the air were used. The change in weight in the different salinities is shown in Fig. 5, weighings being carried out after 6 and $24 \mathrm{~h}$ on samples of twenty larvae. There were changes in weight after $6 \mathrm{~h}$ consistent with water entering the body in salinities up to I I $4 \%$ and being lost in higher salinities. There is a tendency for loss of water at these higher salinities to be corrected after $24 \mathrm{~h}$.

Osmotic concentrations. Freezing-point determinations $(\Delta)$ were made on larvae which had experienced different salinities to see whether these could be correlated with weight changes and salinity tolerance.

$\begin{array}{lcccc}\text { TABLE 4. OSMOTIC CONCENTRATIONS OF NEWLY HATCHED LARVAE } \\ \begin{array}{c}\text { Incubation } \\ \text { salinity } \%\end{array} & (\Delta) & \begin{array}{c}\text { No. of } \\ \text { observations }\end{array} & \Delta \text { (and s.E.) } & \% \% \mathrm{NaCl} \\ 10.9 & (0.65) & 8 & 0.64 \pm 0.002 & 10.7 \\ 32.3 & (1.94) & 10 & 0.74 \pm 0.003 & 12.3 \\ 47.8 & (2.87) & \text { IO } & 0.82 \pm 0.012 & 13.7\end{array}$

First, the mean $\Delta$ 's for ten larvae from each of three incubation salinities (10.9, 32.3 and $47.8 \%$ ) were measured. These are shown in Table 4 . They show that the concentration of the internal body fluids does vary with the external salinity but in high salinities it is regulated and is well below the external salinity. The body-fluid concentration in sea water (here $32 \cdot 3 \%$ ) is 
equivalent to $12 \cdot 3 \%$ of salt. This may be taken as about the normal level for herring larvae in the sea.

Secondly, $\Delta$ 's were determined on larvae which had been transferred from one salinity to another. Three series of experiments were carried out. In the first larvae were transferred from a salinity of $32 \cdot 3 \%$ to a range of salinities

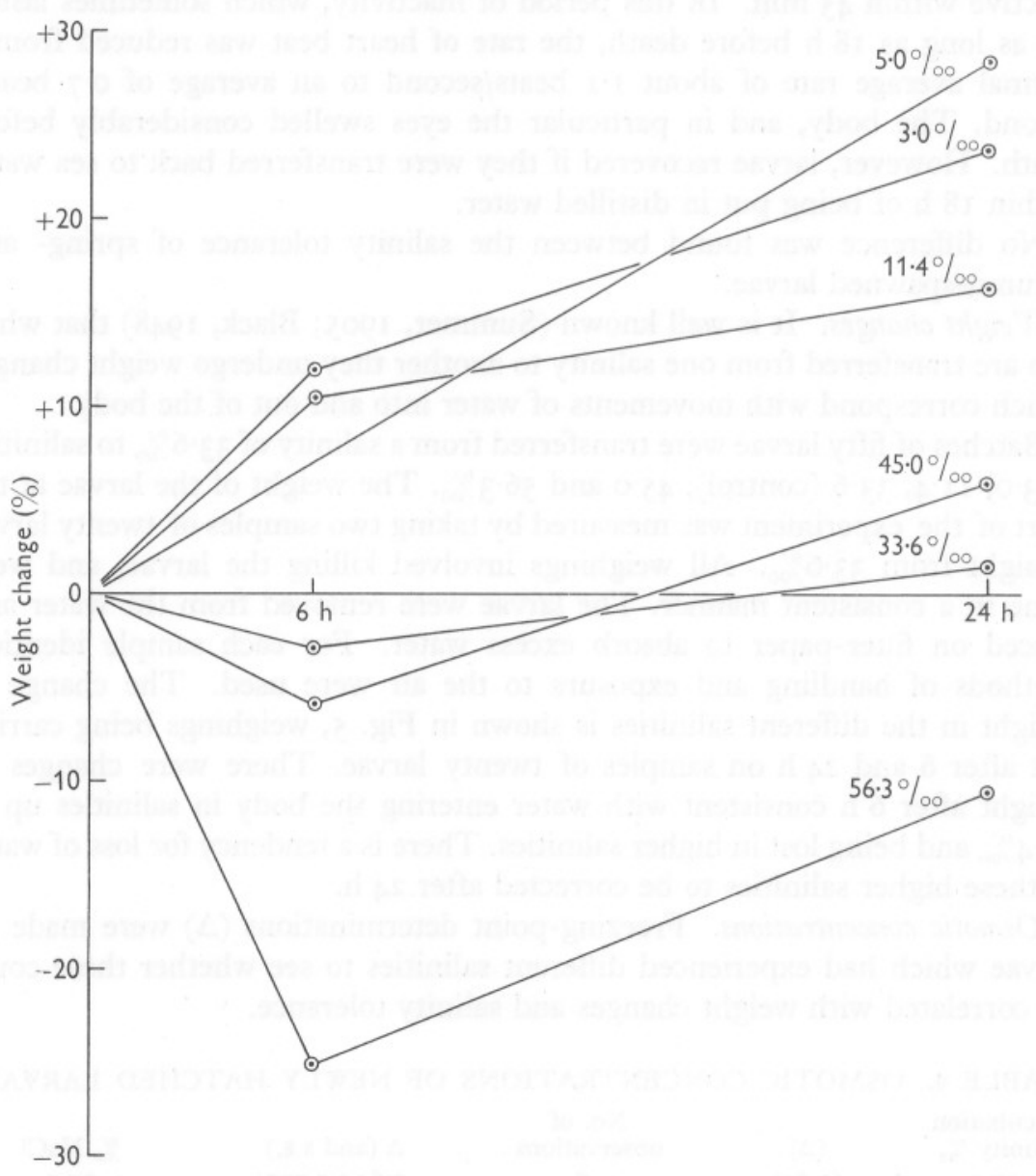

Fig. 5. Changes in weight of larvae when transferred from sea water to the given salinity.

from 3.3 to $60.1 \%$, body-fluid samples being taken after 3,24 and $48 \mathrm{~h}$. The results are shown in Fig. 6. In the second, larvae were transferred from $32 \cdot 3 \%$ o to distilled water, 3.3 and $60.1 \%$ and samples taken after $30 \mathrm{~min}, \mathrm{I} \mathrm{h}$ and $3 \mathrm{~h}$. The results are shown in Fig. 7. Finally larvae from II $2 \%$ were transferred to a range of salinities from 3.3 to $60.1 \%$ and samples of body fluids taken after $24 \mathrm{~h}$ (see Fig. 8). 
The results show that there are considerable changes in the concentration of the body fluids when larvae are transferred, though regulation starts to take place within about $3 \mathrm{~h}$. As samples were only taken from healthy larvae, the tissues of the body can presumably withstand these extremes of 'salinity' which may be as high as $27.5 \%$ and as low as $8.7 \%$ (the normal level being $12 \cdot 3 \%$ ).

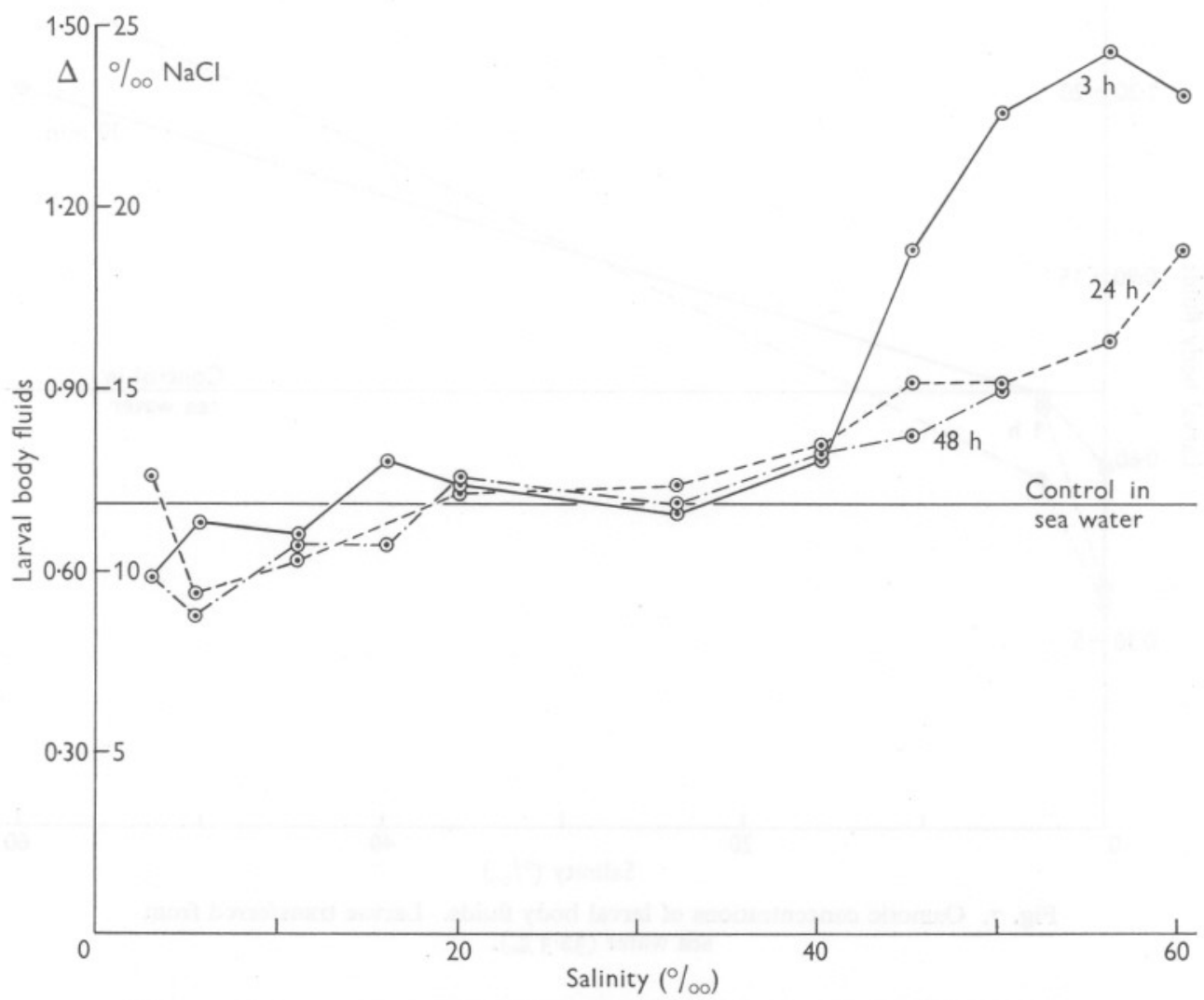

Fig. 6. Osmotic concentrations of larval body fluids. Larvae transferred from sea water $(32 \cdot 3 \%)$.

The levels at which the body fluid concentrations become lethal seem to be equivalent to about 6 and $30 \% \mathrm{NaCl}$.

Sites and mechanisms of regulation. These are considered in adult fish to be the kidney and an extra-renal route for salt exchange, probably in the gill membranes. Very little is known about regulation in fish larvae.

Holstvoogd (I957) found a well-developed pronephric glomerulus and archinephric duct in herring larvae ro $\mathrm{mm}$ long. Serial longitudinal and 
vertical sections were cut of larvae used in these experiments (up to $8.5 \mathrm{~mm}$ long). No sign of a kidney could be found, nor had the gills developed at this stage.

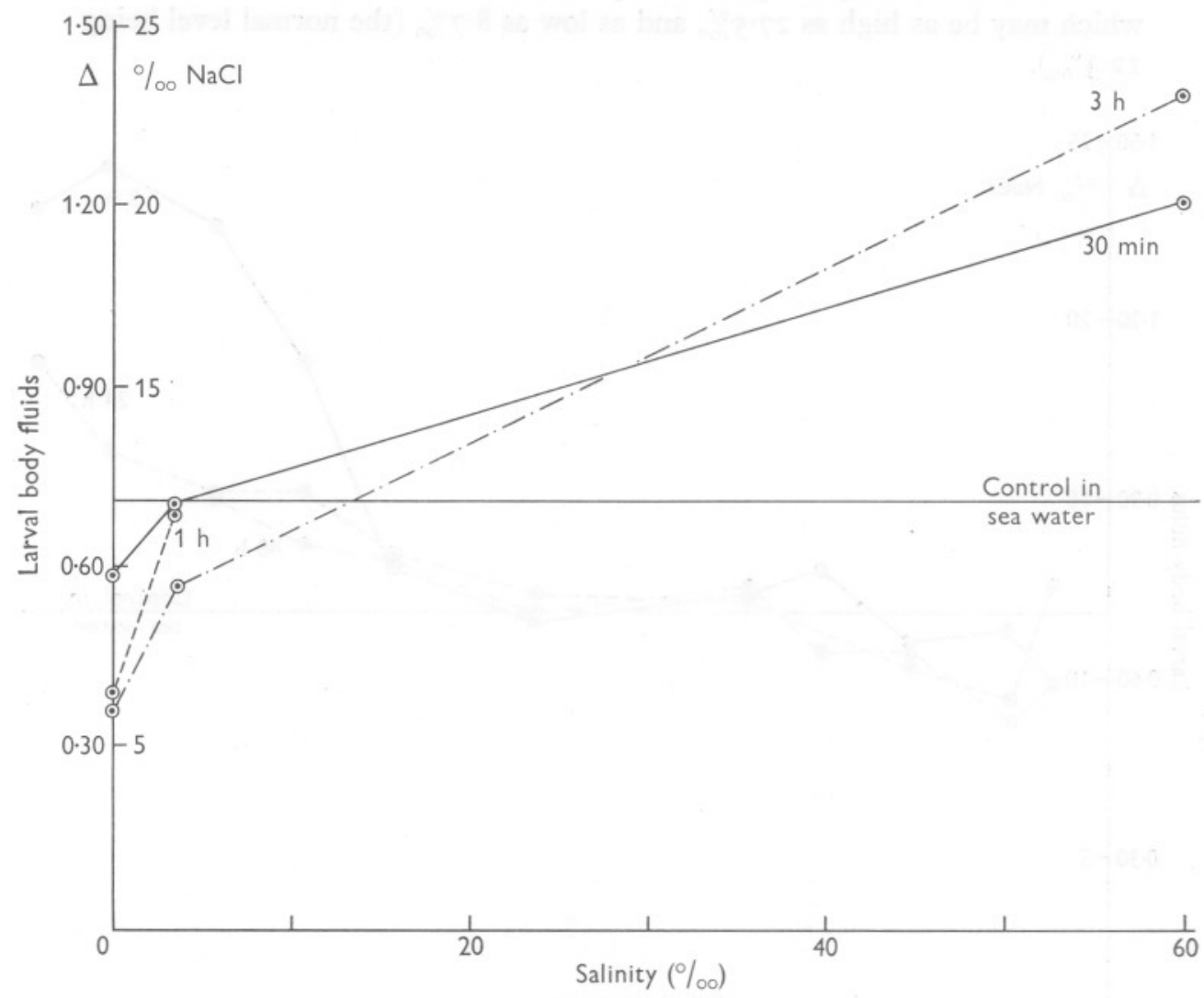

Fig. 7. Osmotic concentrations of larval body fluids. Larvae transferred from sea water $(32 \cdot 3 \%)$.

\section{DISCUSSION}

The most striking results which came from this work are, first, that herring larvae can withstand external salinities ranging from $\mathrm{I} \cdot 4$ to $60 \cdot 1 \%$ for $24 \mathrm{~h}$ and that they have a slightly reduced range of tolerance over longer periods. Secondly, the tissues themselves can withstand for a short time internal concentrations equivalent to salinities of about $9-28 \%$ though the normal value in sea water is $12 \%$. Thirdly, they have a mechanism for regulating the bodyfluid concentration. Thus, when larvae are transferred to salinities within the range of $2.5-52.5 \%$, the body fluids are regulated to equivalent salinities $9 \cdot 8-15.0 \%$. The salinity tolerance of newly hatched larvae is, in fact, wider 
than that of the adult (Holliday \& Blaxter-unpublished to date), although the adult has well-developed sites for regulation. The wider salinity tolerance of the larvae, despite its lack of kidney and gill membranes, is probably due to the greater tolerance of the individual tissues as well as some presumed regulatory process.

The sites of this regulation have not yet been determined; Shelbourne (1957a) suggests the epidermis as a site for the regulation of salt in plaice larvae. The technique used to demonstrate this is not completely specific,

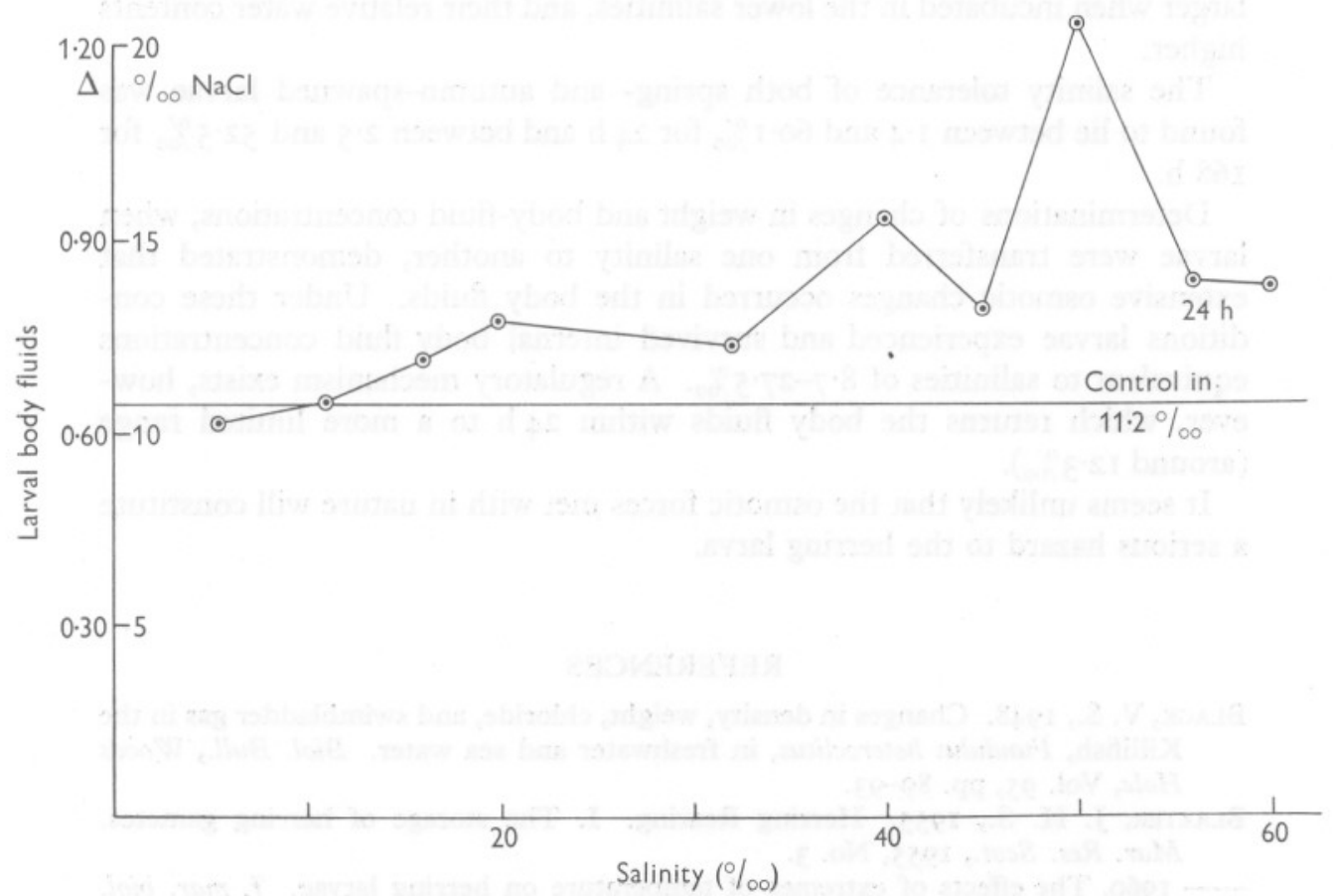

Fig. 8. Osmotic concentrations of larval body fluids. Larvae transferred from salinity $1 \mathrm{I} \cdot 2 \%$.

however, so that the issue is not yet decided. Shanklin (1954) showed in Fundulus embryos that if the glycolytic pathways of metabolism were blocked by specific inhibitors, the embryos failed to osmoregulate, whereas they could normally survive in salinities from tap water to double strength sea water.

The conclusion may be reached that herring larvae are relatively independent of salinity and that they are unlikely to be adversely affected by any salinity change which might take place in the sea or in rearing tanks. They are also more tolerant to salinity than the adult. This is in contrast to Shelbourne's $(\mathrm{I} 957 b)$ conclusions based on work with plaice. He considers that the osmotic hazard is one of the greatest dangers facing plaice larvae and that this danger decreases in the adult stage. 
We should like to thank Dr G. Parry of the Ministry of Agriculture, Fisheries and Food Freshwater Fisheries Laboratory for much advice and help, and to $\mathrm{Mr}$ Parrish of this laboratory for his encouragement and advice.

\section{SUMMARY}

Fertilization, development and hatching of herring eggs occurred in salinities ranging from 5.9 to $52.5 \%$. Both the developing eggs and the larvae were larger when incubated in the lower salinities, and their relative water contents higher.

The salinity tolerance of both spring- and autumn-spawned larvae was found to lie between $\mathrm{I} \cdot 4$ and $60 . \mathrm{I} \%$ for $24 \mathrm{~h}$ and between 2.5 and $52.5 \%$ for I68 h.

Determinations of changes in weight and body-fluid concentrations, when larvae were transferred from one salinity to another, demonstrated that extensive osmotic changes occurred in the body fluids. Under these conditions larvae experienced and survived internal body fluid concentrations equivalent to salinities of $8 \cdot 7-27 \cdot 5 \%$. A regulatory mechanism exists, however, which returns the body fluids within $24 \mathrm{~h}$ to a more limited range (around $12 \cdot 3 \%$ ).

It seems unlikely that the osmotic forces met with in nature will constitute a serious hazard to the herring larva.

\section{REFERENCES}

BLACK, V. S., 1948. Changes in density, weight, chloride, and swimbladder gas in the Killifish, Fundulus heteroclitus, in freshwater and sea water. Biol. Bull., Woods Hole, Vol. 95, pp. 89-93.

BlaxteR, J. H. S., I955. Herring Rearing. I. The storage of herring gametes. Mar. Res. Scot., I955, No. 3.

- 1960. The effects of extremes of temperature on herring larvae. F. mar. biol. Ass. U.K., Vol. 39, pp. 605-8.

BRANDHORST, W., 1959. Spawning activity of the herrings and the growth of their larvae. Int. oceanogr. Congr., New York, Preprints, p. 218.

FORD, E., 1929. Herring Investigations at Plymouth. VII. On the artificial fertilization and hatching of herring eggs under known conditions of salinity with some observations on the specific gravity of the larvae. F. mar. biol. Ass. U.K., Vol. I6, pp. $43-8$.

HoLsTVOoGD, C., I957. The postembryonic development of the pronephros in Clupea harengus L. Arch. néerl. Zool., Vol. 12, pp. 455-66.

Krogh, A., 1939. Osmotic regulation in Aquatic Animals. Cambridge University Press.

MCMYNN, R. G. \& HoAR, W. S., I953. Effects of salinity on the development of the Pacific herring. Canad. F. Zool., Vol. 31, pp. 417-32.

RAmsay, J. A., I949. A new method of freezing-point determination for small quantities. F. exp. Biol., Vol. 26, pp. 57-64. 
RAmsay, J. A. \& Brown, R. H. J., 1955. Simplified apparatus and procedure for freezing-point determinations upon small volumes of fluid. f. sci. Instrum., Vol. 32, pp. 372-5.

Shanklin, D. R., I954. Evidence for active transport in Fundulus embryos. Biol. Bull., Woods Hole, Vol. 107, p. 320.

SHELBOURNE, J. E., 1957 a. Sites of chloride regulation in marine fish larvae. Nature, Lond., Vol. 180, pp. 920-2.

- $1957 b$. The feeding and conditions of plaice larvae in good and bad plankton patches. F. mar. biol. Ass. U.K., Vol. 36, pp. 539-52.

SumNER, F. B., 1905. The physiological effects upon fishes of changes in the density and salinity of water. Bull. U.S. Bur. Fish., Vol. 25, pp. 53-108. 